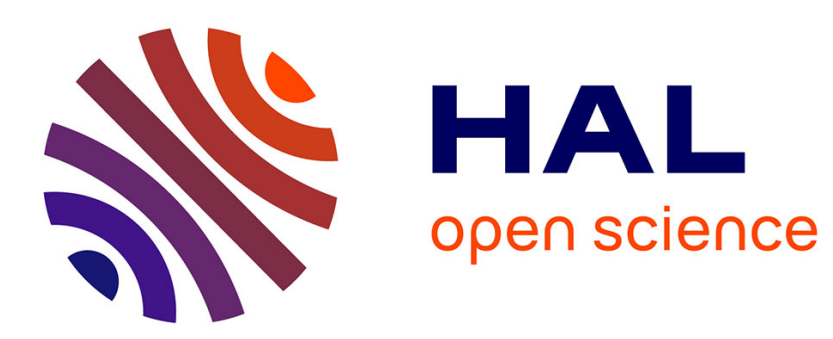

\title{
Interannual variability of atmospheric dimethylsulfide in the southern Indian Ocean
}

\author{
J. Sciare, N. Mihalopoulos, F. Dentener
}

\section{To cite this version:}

J. Sciare, N. Mihalopoulos, F. Dentener. Interannual variability of atmospheric dimethylsulfide in the southern Indian Ocean. Journal of Geophysical Research: Atmospheres, 2000, 105 (D21), pp.2636926377. 10.1029/2000JD900236 . hal-03123395

\section{HAL Id: hal-03123395 \\ https://hal.science/hal-03123395}

Submitted on 28 Jan 2021

HAL is a multi-disciplinary open access archive for the deposit and dissemination of scientific research documents, whether they are published or not. The documents may come from teaching and research institutions in France or abroad, or from public or private research centers.
L'archive ouverte pluridisciplinaire HAL, est destinée au dépôt et à la diffusion de documents scientifiques de niveau recherche, publiés ou non, émanant des établissements d'enseignement et de recherche français ou étrangers, des laboratoires publics ou privés. 


\title{
Interannual variability of atmospheric dimethylsulfide in the southern Indian Ocean
}

\author{
J. Sciare \\ LSCE, Orme des Merisiers, Gif-sur-Yvette, France \\ N. Mihalopoulos \\ ECPL, Department. of Chemistry, University of Crete, Heraklion, Greece \\ F.J. Dentener \\ IMAU, University of Utrecht, Utrecht, Netherlands
}

\begin{abstract}
Continuous measurements of atmospheric dimethylsulfide (DMS) have been performed over a 10-year period (1990-1999) at Amsterdam Island in the southern Indian Ocean. Atmospheric DMS ranges from 5 to 1930 parts per trillion by volume (pptv) and shows a clear seasonal variation with a factor of 20 in amplitude between its maximum in January (austral summer) and minimum in JulyAugust (austral winter). Important deviations from the 10-year monthly mean as high as $100 \%$ have been detected, which could not be explained by changes in meteorology and/or oxidation capacity of the atmosphere. Comparison with a three dimensional (3-D) chemistry/transport model revealed that changes in the source strength of DMS as high as a factor of 2 were required to account for such DMS interannual variations. In addition, DMS variability was found to be closely related to sea surface temperature anomalies, clearly indicating a link between DMS and climate changes.
\end{abstract}

\section{Introduction}

Dimethylsulfide (DMS) is an important sulfur-containing trace gas produced by some classes of marine phytoplankton. It has been suggested that DMS could play an important role in regulating climate through formation of aerosols which could act as cloud condensation nuclei (CCN) [Charlson et al., 1987]. Following the publication of this hypothesis (CLAW hypothesis) by Charlson et al. [1987], numerous field studies reported evidence for a relationship between DMS and its oxidation products in the aerosol phase [Andreae et al., 1991; Ayers et al., 1991; Ayers and Gras, 1991]. In addition, other investigators reported relationships between atmospheric DMS and condensation nuclei $(\mathrm{CN})$ or $\mathrm{CCN}$ concentrations [Andreae et al., 1995; Putaud et al., 1993]. However, as pointed out by Bates and Quinn [1997], the hypothesized feedback link of Charlson ei al. [1987], whereby climate affects the level of DMS emissions, remains elusive. For instance, Bates and Quinn [1997] reported very little interannual variation in seawater DMS concentrations for the equatorial Pacific Ocean $\left(15^{\circ} \mathrm{S}-15^{\circ} \mathrm{N}\right)$ during the 1982 1996 period. These authors also claimed that the large interannual variations in oceanic and atmospheric properties associated with the EI Niño-Southern Oscillation (ENSO) events appear to have little effect on seawater DMS concentrations in surface waters. There are considerable uncertainties associated with the interpretation of ship-cruise measurements for deriving interannual variability. Further, it is not clear if these results are valid for other regions than equatorial Pacific.

We present here the results of 10-year continuous measurements of atmospheric DMS at Amsterdam Island

Copyright 2000 by the American Geophysical Union.

Paper number 2000JD900236.

0148-0227/00/2000JD900236\$09.00 (southern Indian Ocean) since 1990. This data set offers a unique opportunity to address the question of possible DMS interannual variability in the southern Indian Ocean and try to understand the factors controlling it. The long-term atmospheric DMS observations will be contrasted with results of a 3-D chemistry/transport model. Source strength variability will also be discussed as it could be an important factor for DMS variability [Charlson et al., 1987].

Considering a DMS lifetime during summer of the order of 12 days, atmospheric DMS measured at Amsterdam Island is representative for an area of about $6^{\circ}$ in latitude and $8^{\circ}$ in longitude around this island [Sciare et al., 1999]. Therefore the aim of this study is not to conclude on the representativity of the DMS levels measured at Amsterdam Island for the whole Southern Ocean but to examine if any possible link could be established between a climatic parameter and DMS on a regional scale.

\section{Experiment}

Atmospheric DMS measurements are performed at the Pointe Bénédicte sampling station at Amsterdam Island since 1984 and on a regular basis since 1988 . This island is located in the temperate southern Indian Ocean ( $\left.37^{\circ} 50^{\prime} \mathrm{S}, 77^{\circ} 30^{\prime} \mathrm{E}\right), 3000 \mathrm{~km}$ off the nearest continents and benefits most of the year of pristine oceanic conditions. More details on the climatology of this island can be found at Polian et al. [1986] and Miller et al. [1993].

Atmospheric DMS is collected at $0800 \mathrm{LT}$ by compressing air during $15 \mathrm{~min}$ into electropolished stainless steel canisters. Analysis is conducted "in situ," immediately after collection, by DMS preconcentration on a Tenax trap hold at $-80^{\circ} \mathrm{C}$. DMS is consequently analyzed by using a gas chromatograph equipped with a flame photometric detector (FPD). More details on the analytical technique are given by Nguyen et al. [1990].

The sampling and analysis technique was successfully compared with other "classical" DMS measurement techniques 
during ACE 2 experiment (J.P. Putaud, personal communication, 1998). A similar comparison of our "canisters" technique and an "on-line" sampling system (same system but avoiding the storage in canisters) was also performed at Amsterdam Island in January 1998 [Sciare et al., 2000a]. Percentage difference between the two techniques was found to be $\pm 5.4 \%(n=8)$. Additional tests were performed to check the stability of DMS in the canisters. Percentage change was less than $7 \%$ for a 10 -day storage in canisters at Amsterdam Island and expected to be negligible for our experiment. Finally, tests were performed by trapping a given amount of DMS and injecting variable volumes of ambient air collected with the canisters. DMS recovery was found to be of the order of $100 \pm 5 \%(n=16)$. Reproducibility defined as the variance of five replicate analysis was better than $3 \%$.

Particular attention has been paid to maintain the same protocol (same analytical setup, calibration, time of collection) during the whole period (1990-1999).

Daily DMS calibration, following the analysis, was performed by the mean of permeation tubes (wafer-type permeation source, VICI Metronics, Santa Clara, Califomia). The permeation tubes used at Amsterdam Island were calibrated against a primary permeation tube. The flow rate of this primary tube $(7.90 \mathrm{ng} / \mathrm{min})$ was certified in 1990, 1993, and 1995 both gravimetrically and by using liquid DMSP standards and showed no significant change (less than 6\%) within these 5 years. Since January 1995, all the permeation tubes used at Amsterdam Island have been certified against this primary permeation tube and have been also checked on a yearly basis using liquid DMSP standards. Flow rates of the secondary tubes again did not present significant change (error of 6\%) for the last 5 years. Although the continuous atmospheric DMS measurements began in 1988, results for the period 1988-1990 are not presented here, since the calibration tubes used at that period could not be rechecked. However, further analysis revealed that this data set is consistent with ours and better improve the conclusions drawn in this paper between DMS and sea surface temperature (SST).

Preliminary results showed that DMS measurements performed at $0630 \mathrm{LT}$ was of the order of $15 \%$ higher than the daily average DMS value [Putaud et al., 1992]. From an intensive experiment performed during January 1998, when the highest DMS diumal variations from $\mathrm{OH}$ photochemistry are expected, it was found that the DMS value measured at $0800 \mathrm{LT}$ was of the order of $17 \%$ higher than the daily average DMS value (Figure 1) (correlation coefficient $r^{2}=0.89, n=27$ ). This value

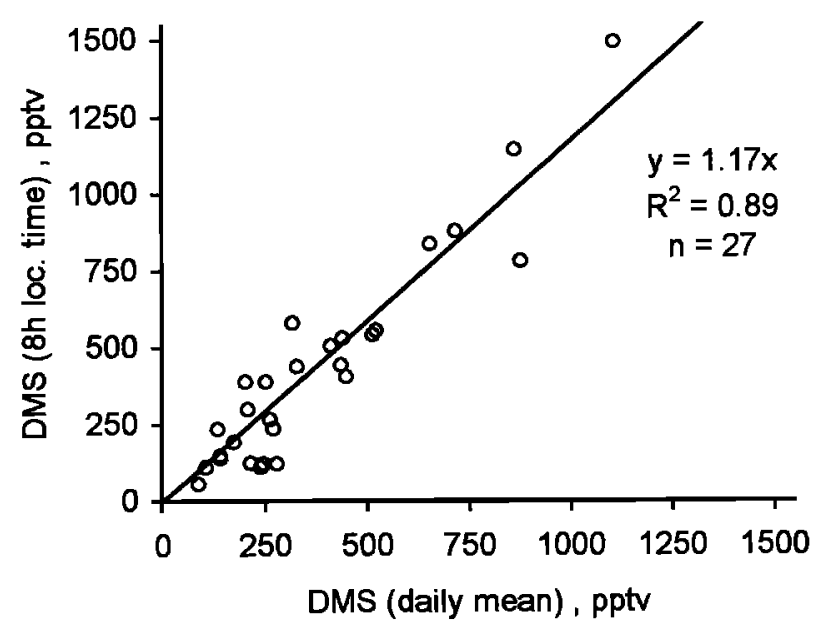

Figure 1. Comparison between DMS value measured at $0800 \mathrm{LT}$ and the daily mean value (see text for explanation).
(17\%) can be considered as an upper limit since (1) during January 1998 no DMS measurements have been performed during nighttime (0000-0500 LT) and (2) during wintertime, daytime oxidation by $\mathrm{OH}$ decreases greatly. Thus the time of collection $(0800 \mathrm{LT})$ gives a good representation of the atmospheric DMS daily mean.

All the meteorological parameters (wind, insolation, relative humidity, air temperature, pressure, marine boundary layer (MBL) height) were provided by the local meteorological station (referenced as WMO / 61996).

\section{Results and Discussion}

\subsection{Seasonal Variation of DMS}

Figure 2 reports atmospheric DMS mixing ratios measured from August 1990 to December 1999 on a daily basis. Atmospheric DMS ranges from 5 to 1930 pptv and shows a clear seasonal variation with a factor of 15 in amplitude between its maximum in January during the austral summer and its minima in July and August during the austral winter. Monthly mean and median concentrations were calculated for the 10 years of DMS measurements and the results are presented in Table 1 in conjunction with the seasonal variation of several meteorological parameters, which will be discussed later. Median DMS concentrations are on average $35 \%$ lower compared to mean levels, however, the seasonal trend is comparable $(6 \%$ difference).

As reported by several authors [Nguyen et al., 1990; Andreae, 1990], such a seasonal cycle reflects a similar cycle in DMS concentration in seawater induced by enhanced phytoplanktonic activity. Atmospheric DMS values pre-sented in Figure 2 are among the highest reported in the literature [Andreae, 1990; Yvon et al., 1996; Bates et al., 1992]. During summertime the measured DMS mixing ratios were a factor of 3.5 higher compared to values obtained at Cape Grim (Tasmania), located roughly at the same latitude as Amsterdam Island [Ayers et al., 1995]. The high DMS sea-to-air fluxes in the area around Amsterdam Island, with values of the order of $15 \mu \mathrm{mol} / \mathrm{m}^{2} / \mathrm{d}$ during summer (a factor of 3 compared to those reported for Cape Grim), can account for the high DMS mixing ratios observed during summer [Sciare et al., 1999].

Note that local/coastal influence on the DMS levels can be neglected due to the absence of continental plateau around Amsterdam Island (depth at $1000 \mathrm{~m}$ at $2 \mathrm{~km}$ offshore the island). Transect profiles of seawater DMS from the island to the open ocean confirms this observation [Nguyen et al., 1992].

\subsection{Interannual Variations of DMS}

Several conclusions emerge from our data set reported in Figure 2. First, a pronounced seasonal pattern in DMS is visible every year although the DMS maxima change both in terms of intensity and in duration from a year to another. Secondly, a strong interannual variability is observed in the monthly signal, which is more evident during the summer months, when the DMS mixing ratios are the highest.

To identify the significance of the year-to-year atmospheric DMS changes, we report the monthly mean DMS "anomalies" for this 10-year period in Figure 3, calculated as the difference between the mean of a given month and the corresponding 10year monthly mean value. The months from December to March represent the most productive period in terms of DMS emission and account for roughly two thirds of the total DMS amount emitted on an annual basis [Nguyen et al., 1990]. Since DMS anomalies observed during these summer months could be quite 


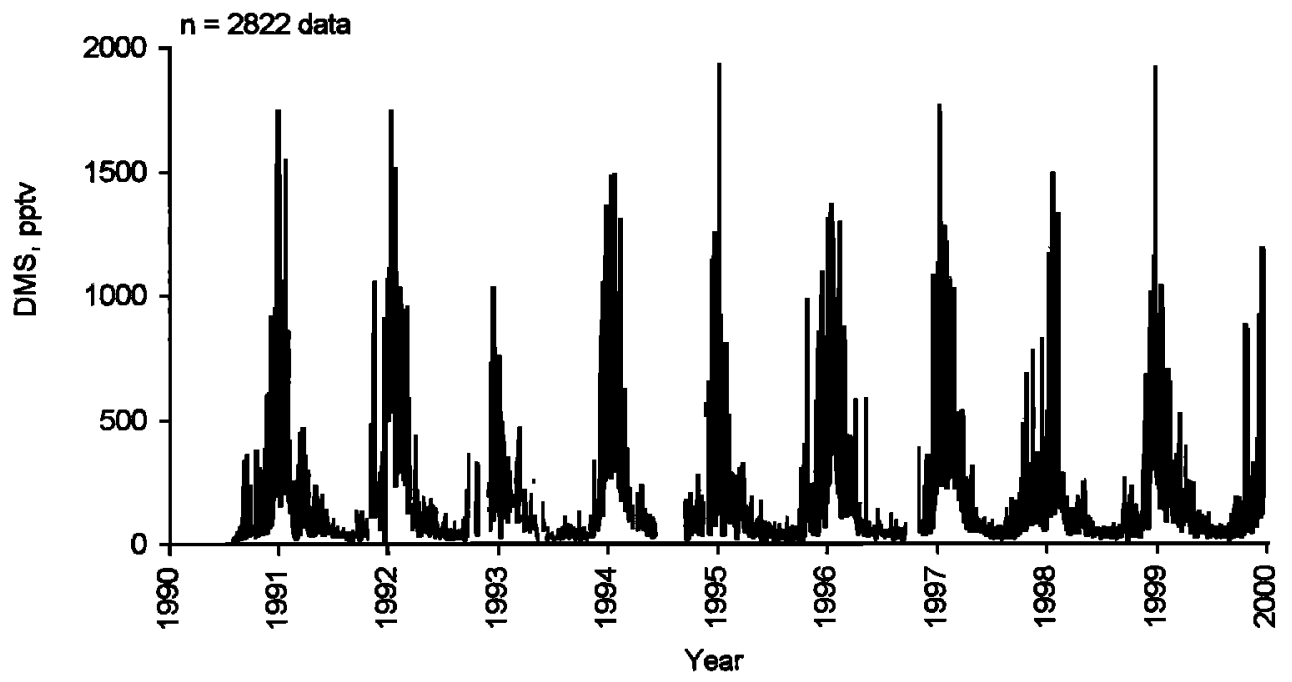

Figure 2. Atmospheric DMS mixing ratios measured on a daily basis at Amsterdam Island from August 1990 to December 1999.

relevant for the possible DMS-climate impact (highest DMS levels), our discussion will focus on these months. Missing values for the months from December to March (1990-1998) do not exceed 9\%; that is, there are less than 3 days missing for each month.

During the summer months the mean DMS mixing ratios (in pptv) and standard deviation were $363 \pm 134,570 \pm 171,364 \pm 131$, and $214 \pm 86$ for December, January, February, and March, respectively (Table 1 ). Thus only months with a mean value below or above these ranges have been considered as DMS "anomalies." By using statistical analysis (difference between population means of large samples), three positive anomalies (January-February 1992; January-February 1994; FebruaryMarch 1997) and one negative anomaly (January-February 1993) have been distin--guished (positive/negative sign in Figure 3). The mean DMS value during these months was significantly different (probability higher than $99 \%$ ) from the corresponding 10-year monthly mean.

To our knowledge, no other long-term measurements of DMS do exist in the Indian Ocean to compare our DMS anomalies. DMS has been measured at Cape Grim (Southern Ocean) during the 1988-1993 period, using wind and $\mathrm{CN}$ criteria (Southwest winds and $\mathrm{CN}<600 \mathrm{~cm}^{-3}$ ) [Ayers et al., 1995]. Although these measurements were not conducted on a continuous basis and not at the same hour of the day as done at Amsterdam Island, they present a similar trend. Especially the drastic decrease in January 1993 reported at Amsterdam Island is also clearly visible in the Cape Grim data. Methanesulfonic acid (MSA), an exclusively DMS oxidation product, has been continuously measured since 1988 at Amsterdam Island [Mihalopoulos et al., 1993; E. Baboukas et al., unpublished data, 2000]. MSA deposition fluxes anomalies calculated at this location correspond in most of the

Table 1. Seasonal Variations of Atmospheric DMS (Mean and Median) and Seasonal Variations of Various Meteorological Parameters for the period 1990-1999

\begin{tabular}{lcccccccc}
\hline \multicolumn{1}{c}{ Month } & $\begin{array}{c}\text { Mean DMS } \\
(\mathrm{pptv})\end{array}$ & $\begin{array}{c}\text { Median DMS } \\
(\mathrm{pptv})\end{array}$ & $\begin{array}{c}\text { Wind Speed } \\
(\mathrm{m} / \mathrm{s})\end{array}$ & $\begin{array}{c}\text { N sector } \\
\text { Occurrence }(\%)\end{array}$ & $\begin{array}{c}K_{w} \\
(\mathrm{~cm} / \mathrm{h})\end{array}$ & $\begin{array}{c}\text { MBL Height } \\
(\mathrm{m})\end{array}$ & $\begin{array}{c}\text { Insolation } \\
(\mathrm{h})\end{array}$ & $\begin{array}{c}\text { SST } \\
\left({ }^{\circ} \mathrm{C}\right)\end{array}$ \\
\hline January & $570(30)$ & 337 & 5.8 & $54(8)$ & $5.9(22)$ & $1273(13)$ & $185(44)$ & $17.6(2.8)$ \\
February & $364(36)$ & 253 & 6.0 & $50(13)$ & $6.4(32)$ & $1344(13)$ & $161(28)$ & $18.3(4.3)$ \\
March & $214(40)$ & 133 & 6.1 & $51(5)$ & $6.4(29)$ & $1365(6)$ & $121(19)$ & $17.9(5.8)$ \\
April & $112(19)$ & 75 & 6.7 & $46(9)$ & $7.4(20)$ & $1382(8)$ & $111(23)$ & $16.9(6.1)$ \\
May & $85(19)$ & 56 & 7.6 & $49(8)$ & $9.3(21)$ & $1462(6)$ & $106(16)$ & $15.5(4.2)$ \\
June & $58(12)$ & 49 & 9.1 & $53(5)$ & $12.1(24)$ & $1343(7)$ & $97(15)$ & $14.1(3.0)$ \\
July & $38(13)$ & 35 & 10 & $52(8)$ & $13.8(23)$ & $1373(7)$ & $109(15)$ & $13.3(2.7)$ \\
August & $39(12)$ & 32 & 8.8 & $57(5)$ & $10.8(17)$ & $1419(13)$ & $118(12)$ & $12.9(2.2)$ \\
September & $65(35)$ & 39 & 8.8 & $58(12)$ & $12.2(15)$ & $1458(7)$ & $132(14)$ & $13.0(2.4)$ \\
October & $113(45)$ & 63 & 7.3 & $58(5)$ & $8.1(13)$ & $1498(10)$ & $128(10)$ & $13.4(2.2)$ \\
November & $164(38)$ & 88 & 7.2 & $64(4)$ & $8.1(18)$ & $1325(11)$ & $164(18)$ & $14.3(3.9)$ \\
December & $363(37)$ & 151 & 6.6 & $58(6)$ & $7.3(20)$ & $1250(8)$ & $173(15)$ & $15.8(1.9)$ \\
\hline
\end{tabular}

The values in parentheses correspond to variance [ $(1 \sigma /$ mean value $) \times 100]$. Wind speed, $N$ sector occurrence and $K_{w}$ is averaged on 3-hourly observations MBL height, insolation and SST are averaged on dally observations. 


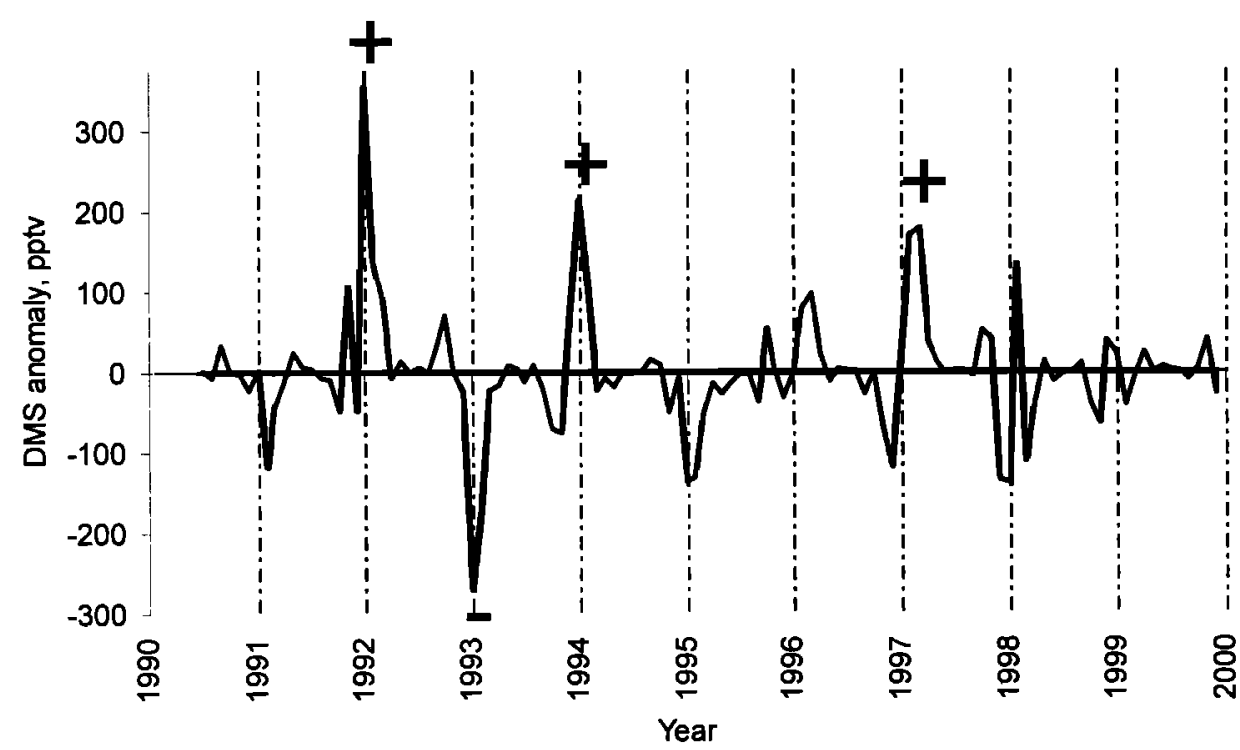

Figure 3. DMS anomalies calculated from the experimental data at Amsterdam Island from August 1990 to December 1999. Plus and minus displayed in this figure correspond to the periods of DMS anomalies (see text).

cases to the DMS anomalies, suggesting a larger-scale representativity of our DMS anomalies [E. Baboukas et al., unpublished data, 2000].

3.2.1. What factors control atmospheric DMS changes at Amsterdam Island? Changes in the oceanic DMS source, meteorology, and/or oxidation capacity of the atmosphere could account for the observed DMS anomalies.

The exchange of DMS between the ocean and the atmosphere can be described with a simple resistance model, dependent on the oceanic DMS concentrations and a corresponding transfer velocity coefficient $\left(K_{w}\right)$ [Liss and Merlivat, 1986]. $K_{w}$ is a strong nonlinear function of the wind speed, favoring high wind speeds.

3.2.1.1. Wind speed and direction: The key factors controlling the short-term variations of atmospheric DMS at Amsterdam Island during summer were investigated during a 1month period (January 1998) [J. Sciare et al, unpublished data. 2000]. A significant correlation has been reported between atmospheric DMS and $K_{w}$ for both the north $\left(280^{\circ}-80^{\circ}\right)$ and the south wind sectors $\left(260^{\circ}-80^{\circ}\right)$. Such good correlation underlined the importance of wind speed on the DMS levels on a monthly basis. The slope between $K_{w}$ and mixing ratios of atmospheric DMS was a factor of 2 higher for the north compared to the south sectors. This factor confirmed the existence of a stronger DMS oceanic source north to the island for January, in line with the results reported for the month of December [Sciare et al., 1999]. Thus wind speed as well as wind direction can significantly influence the DMS levels measured at Amsterdam Island.

3.2.1.2. MBL height: Very few studies reported the vertical distribution of atmospheric DMS in the MBL [Andreae et al., 1988; Berresheim et al., 1990]. To our knowledge, no studies have been carried out to examine the possible impact of the MBL height on the DMS mixing ratios measured at ground level. The day-to-day MBL variability as a possible factor controlling atmospheric DMS was investigated at Amsterdam Island in January 1998 [J. Sciare et al., unpublished data, 2000]. The lowest MBL heights were often observed before the arrival of low-pressure systems and were associated with high north wind speed. Thus it was difficult to separate the influence of each parameter on the DMS levels. However, through a 1-month period (January 1998) no significant correlation could be observed between atmospheric DMS and MBL heights $\left(r^{2}=0.17\right)$ In addition, no clear seasonal variation was reported for the MBL height (Table 1).

3.2.1.3. Photochemistry: Photochemical reactions involving $\mathrm{OH}$ and possibly BrO radicals are currently proposed as the main mechanisms for removal of atmospheric DMS in the clean marine atmosphere [Ayers et al., 1995; Sciare et al., 2000b]. DMS diel variations were reported at Amsterdam Island for the month of January [J. Sciare et al., unpublished data, 2000] with a DMS ratio (maximum/minimum) of 1.6 in very good agreement with the 1.7 calculated by Ayers et al. [1995] for Cape Grim. Such ratio can be attributed to the fractional variance in concentration caused by the DMS oxidation mechanisms. Thus changes in solar radiation can in turn influence the $\mathrm{OH}$ radical concentration and, consequently, the DMS removal from the atmosphere.

3.2.2. Do the above mentioned meteorological factors, which control the daily atmospheric DMS levels, also explain the interannual DMS changes? Table 2 presents the percentage difference of the DMS anomalies compared to the whole data set of the 10-year period as well as the percentage difference of anomalies (1) in $K_{w}$ (to better express the effect of wind speed), (2) in occurrence of North sector winds (Occ N, all the wind sectors north to Amsterdam Island, i.e., between $280^{\circ}$ and $80^{\circ}$ ), (3) in insolation (INS), and (4) in MBL height. As displayed in Table 2 , in most of the cases the DMS deviations from the mean cannot be explained by the observed variability in the meteorological parameters. For instance, during January 1992 and March 1997, where the most important positive anomalies have been observed ( 63 and $83 \%$, respectively), $K_{w}$ was 16 and $24 \%$ lower than the mean value. In addition, there was no significant change in the North sector occurrence during these months. A part of the January 1992 anomaly could be explained by the small change in insolation (less $\mathrm{OH}$ radicals), but this is not definitively the case for March 1997, where no change in insolation has been observed. In addition, during January 1993 the most important negative "anomaly" has been observed under conditions of high wind speeds and low photochemistry. A first conclusion, drawn from the qualitative comparison between DMS and meteorological parameters depicted in Table 2, is that 
Table 2. Percentage Difference Between a Month and Its Corresponding Mean (Reported in Table 1) for atmospheric DMS, $K_{w}, N$ sector occurrence, and MBL Height, for Some Relevant Periods of DMS Anomalies

\begin{tabular}{|c|c|c|c|c|c|}
\hline $\begin{array}{l}\text { Months of Relevant } \\
\text { Anomalies }\end{array}$ & $\begin{array}{c}\text { DMS } \\
\text { Anomalies (\%) }\end{array}$ & $\begin{array}{c}K_{w} \\
\text { Anomalies (\%) }\end{array}$ & $\begin{array}{c}\text { Sector Occurrence } \\
\text { Anomalies (\%) }\end{array}$ & $\begin{array}{c}\text { Insolation } \\
\text { Anomalies (\%) }\end{array}$ & $\begin{array}{l}\text { MBL Height } \\
\text { Anomalies (\%) }\end{array}$ \\
\hline Jan. 1992 & 63 & -16 & $\overline{9}$ & -18 & \\
\hline Feb. 1992 & 37 & -7 & -7 & 43 & 7 \\
\hline Jan. 1993 & -47 & 40 & 3 & -23 & \\
\hline Feb. 1993 & -49 & -22 & -6 & -8 & \\
\hline Jan. 1994 & 38 & -15 & 9 & -21 & -2 \\
\hline Feb. 1994 & 28 & -11 & 15 & 5 & 4 \\
\hline Feb 1997 & 46 & -54 & -7 & 23 & \\
\hline March 1997 & 83 & 24 & -13 & 4 & 6 \\
\hline
\end{tabular}

parameters other than meteorology are needed to describe the observed DMS anomalies.

\subsection{Comparison With Model}

To assess in a more quantitative way the composite role of meteorological parameters (especially the dependence of wind speed) and photochemistry, a 3-D global chemistry/transport model (tracer model version 3, TM3) has been used to calculate the interannual DMS variations at Amsterdam Island [Houweling et al., 1998; Dentener et al., 1999]. The TM3 model is an updated version of TM2 described by Heimann [1993]. In this study, the model is driven by precalculated time-dependent threedimensional meteorological fields from the 1993 reanalyses of the European Centre for Medium-Range Weather Forecasts (ECMWF) model [Gibson et al., 1997] and analyzed wind speeds for 1994-1997. Tracer transport by the three-dimensional air mass fluxes resolved on the model grid (advection) is calculated using the "slopes scheme" of Russel and Lerner [1981]. Vertical transport due to convective clouds is computed using the cloud mass flux scheme of Tiedke [1989], while turbulent vertical transport is calculated by stability-dependent vertical diffusion according to the scheme by Louis [1979]. Using the radionuclide ${ }^{222} \mathrm{Rn}$, synoptic scale transports were shown to be reproduced realistically at Amsterdam Island [Dentener et al., 1999]. In the version used in this study, the spatial resolution is $5^{\circ}$ longitude and $3.75^{\circ}$ latitude with 19 vertical layers, which near the surface are defined as terrain-following sigma coordinates, in the stratosphere (up to $10 \mathrm{hPa}$ ) by pressure levels and in between by a hybrid of the two. Five layers are located in the boundary layer (BL), eight in the free troposphere and six in the stratosphere. Midlevels for the five layers in the BL are at 32, 145, 385, 790, and $1390 \mathrm{~m}$, respectively. Levels of DMS at 145 and $790 \mathrm{~m}$ were, $80 \%$ and $60 \%$, respectively, of the DMS value at $32 \mathrm{~m}$, which appear realistic compared to vertical DMS measurements reported in the southern Indian Ocean [Andreae et al., 1988; Berresheim et al., 1990]. Through the studied period, little variability could be observed in the ratio DMS (790m)/DMS (32 $\mathrm{m}$ ), indicating a low impact of the MBL height on the DMS levels predicted by the model.

The chemical scheme is a modification of CBM4 (carbon bond mechanism version 4), which considers the background $\mathrm{CH}_{4}, \mathrm{CO}, \mathrm{HO}_{\mathrm{x}}$ and $\mathrm{NO}_{\mathrm{x}}$ chemistry as well as nonmethane hydrocarbons (NMHC) reactions [Houweling et al., 1998]. The CBM4 scheme was modified to include, for example, peroxy radical self-reactions, which are important in the unpolluted background atmosphere. In addition, the model considers reactions and components involved in the sulfur and reduced
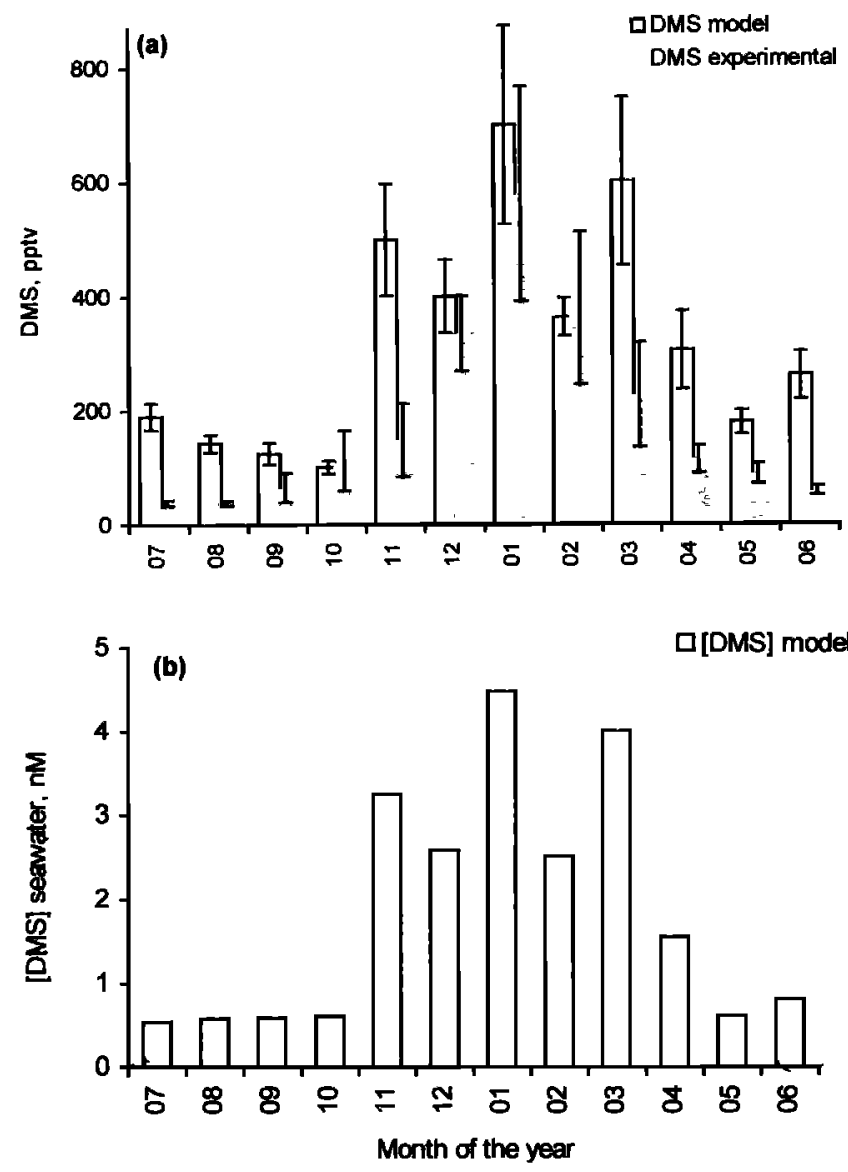

Figure 4. (a) Seasonal variation of atmospheric DMS concentrations derived from the experimental data and the model, (b) seawater DMS concentrations used as input parameter in the model. 
nitrogen cycle $\left(\mathrm{SO}_{2}, \mathrm{NH}_{3}, \mathrm{NH}_{4}, \mathrm{SO}_{4}\right.$, and MSA). The influence of clouds was explicitly accounted for by the use of ECMWF 6hourly varying cloudiness, allowing explicit oxidation chemistry occurring in cloud droplets. Further, the influence of clouds on photodissociation rates was explicitly accounted for, following the method of Krol and Weele [1997] and Landgraf and Crutzen [1999]. DMS emissions were dependent through $K_{w}$ on the 6hourly varying model wind speeds. TOMS satellite measurements were used to constrain stratospheric ozone, inducing variability of irradiation at the Earth's surface and $\mathrm{OH}$ radical. Changes in emissions of $\mathrm{O}_{3}$ precursors were taken into account on an annual basis. DMS was calculated using a gridded monthly varying ocean DMS concentration data sets [Kettle et al., 1999] and the exchange velocities as described above. Atmospheric DMS is destroyed by reactions with $\mathrm{OH}$ and $\mathrm{NO}_{3}$ radicals. Atmospheric DMS at Amsterdam Island was derived as the average of the mixing ratios calculated in four surface grid boxes of the model covering an area roughly $8^{\circ}$ in latitude and $10^{\circ}$ in longitude and centered at this island. Given the lifetime of DMS during summer, such area is sufficient to describe the DMS pattern at Amsterdam Island [Sciare et al., 1999].

A comparison was performed for a 6-year period (1991-1997) between the monthly mean $K_{w}$, calculated by using the local meteorological parameters (average of $K_{w}$ calculated every 3 hours), and monthly mean $K_{w}$ calculated by the model (average of $K_{w}$ calculated every 6 hours). All the $K_{w}$ (from meteorological data and from model) were calculated using the Liss and Merlivat [1986] parameterization. A good agreement was found between the two data sets (correlation coefficient $r^{2}=0.89, n=72$ ) with values given by the model roughly $15 \%$ higher than those calculated from the local meteorological parameters. Thirty-meter height winds as used in the model instead of surface winds could account for this difference.

Figure 4a reports the DMS seasonal variations obtained from the measurements (1990-1999) and from the model (1990-1996). Note that differences in seasonal and interannual DMS variations are not significant (less than $3 \%$ ) if measurements are restrained to the period 1990-1996 (as for model).

A clear seasonal variation was observed for DMS predicted by the model and in phase with observations. During winter the model overestimates the DMS mixing ratio by a factor of 3 . Also during spring and autumn the major differences are found for
November and March with model concentrations reaching 500 and 601 pptv, respectively, i.e., a factor of 2-3 higher compared to the observations. The (DMS) seawater $_{\text {seasonal cycle used in the }}$ model [Kettle et al., 1999] and reported in Figure 4b can account for most of the difference between experimental and modeling results. The very significant correlation coefficient $\left(r^{2}=0.96\right.$; $(\mathrm{DMS})_{\text {seaweter }}=6.5 \times 10^{-3}(\mathrm{DMS})_{\text {air; }}$ equation (1)) indicates that the differences observed in atmospheric DMS in Figure 4a during summer can be mostly explained by the seasonal variation in the seawater DMS concentrations used in the model. This is not the case for the winter months where changes in atmospheric DMS predicted by the model are driven by changes in $K_{w}$. Focusing on the summer months (December, January, February), the difference in DMS concentrations between measurements and model (Figure $4 \mathrm{a}$ ) is reduced to $16 \%$, which is also the difference between $K_{w}$ calculated from measurements and model. Since the present discussion focuses on DMS anomalies observed for the summer months, such small differences will facilitate the comparison of observed and model DMS anomalies.

Strong DMS interannual variations were calculated by the model and driven by changes in meteorological conditions (mainly wind speed). Figure 5 presents the DMS anomalies obtained from the DMS modeling results and calculated as for the experimental results. The highest anomalies calculated from the modeling data were observed during the summer months, as in the case of the experimental results (see also Figure 5). As shown in this figure, the model results cannot reproduce the observed DMS variability. In fact, the model simulates negative anomalies when positive have been observed (periods of JanuaryFebruary 1992 and January-February 1994). The opposite signal is also found for January 1993. Thus neither meteorological variability nor the year-to-year changes in photochemistry can account for the observed DMS anomalies, which is in agreement with our previous findings.

\subsection{Factors Controlling the Interannual DMS Variations}

The only remaining parameter relevant to atmospheric DMS which did not vary from year to year in the 3-D CTM model was the DMS seawater concentration, which was derived from a measurement climatology [Kettle et al., 1999]. We can thus reasonably assume that a strong interannual variability in this

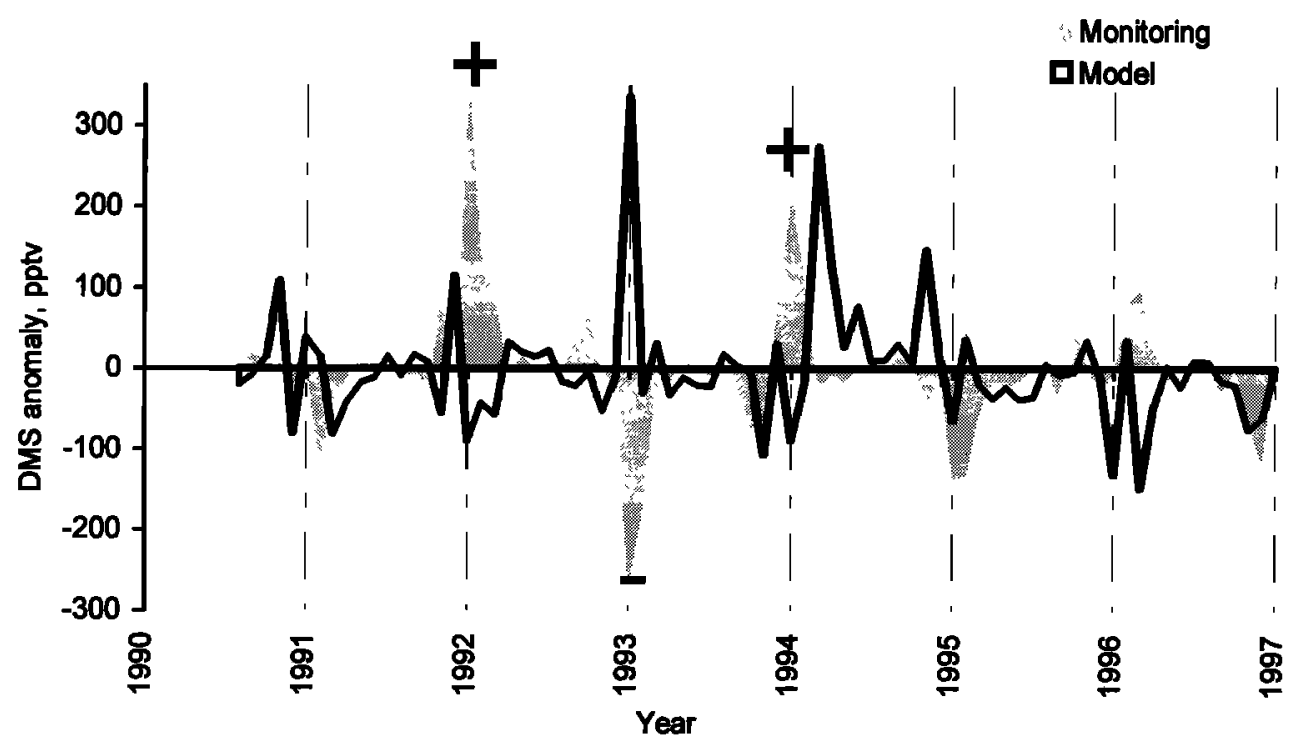

Figure 5. Comparison between DMS anomalies calculated from the monitoring and the model results. 


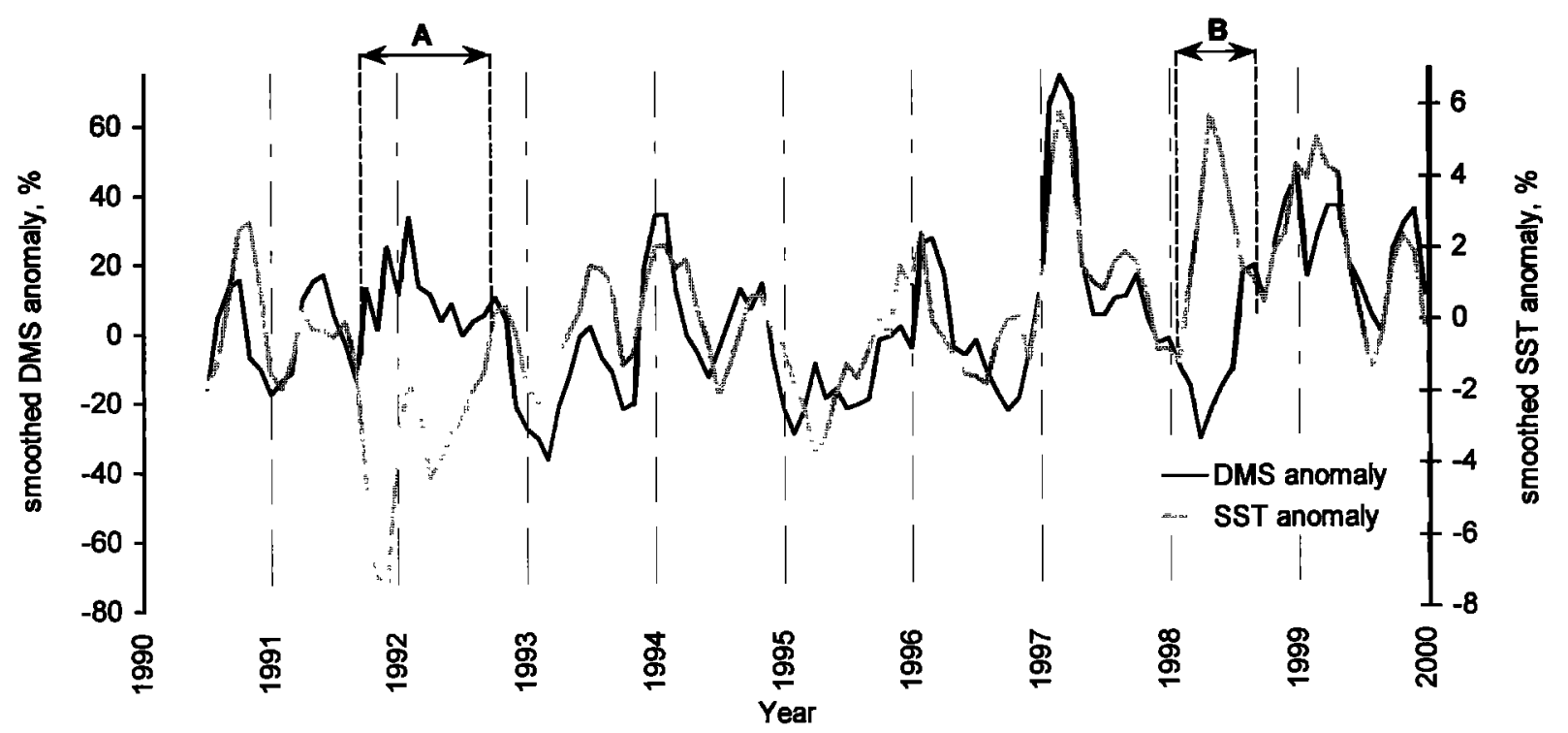

Figure 6. Comparison between DMS and SST anomalies (smoothed on a 3-month basis) between August 1990 and December 1999. SST anomalies were calculated from IGOSS monthly mean SST data obtained at $\left(37.5^{\circ} \mathrm{S}, 74.5^{\circ} \mathrm{E}\right)$.

parameter is needed to reconcile the modeled DMS mixing ratios with the observations. Since variations in the seawater DMS concentrations during summer are closely reflected in the atmospheric DMS variations in the model (equation (1)), this equation can be used to estimate the changes in the oceanic DMS source needed to fit the observed and modeled DMS mixing ratios. To bring in better agreement the opposite trend observed during summer 1993, a decrease in seawater DMS concentration by more than a factor of 2 is needed (decrease of $2.5 \mathrm{nM}$ when equation (1) is used). Similarly for the positive anomalies observed in January 1992 and 1994, increases in seawater DMS by about 3.5 and $2.2 \mathrm{nM}$ are, respectively, needed.

No systematic studies have been carried out to evaluate the year-to-year seawater DMS variability in the southern Indian Ocean to validate such important change. In addition, the ocean color obtained by satellites and representative of the marine biomass is not available for the whole investigated period to verify our hypothesis.

Given the presence of a productive area north to the island (33-39 $\mathrm{S}$ [Sciare et al, 1999 and unpublished data]), one might suggest that a drift of this area could affect the DMS interannual variability at Amsterdam Island. Indeed, any northward drift should decrease the DMS levels from $\mathrm{N}$ sector, and on the other hand, any southward drift should increase the DMS levels from S sector. In other words, any drift should modify the monthly mean DMS concentrations for the $\mathrm{N}$ and/or $\mathrm{S}$ sectors, inducing different anomalies for both sectors. However, the DMS anomalies calculated for both sectors were similar to those previously reported for all sectors.

Following the CLAW hypothesis, changes in sea surface temperature (SST) are expected to affect DMS emissions from seawater and, consequently, its atmospheric concentrations. Sciare et al. [1999] and Belviso et al. [2000] showed that changes in SST through frontogenesis can strongly influence the seawater DMS concentrations in the Indian and Atlantic Oceans, respectively. On the other hand, Bates and Quinn [1997] found no interannual variability in seawater DMS in the equatorial Pacific Ocean, an area affected by the El Niño-Southern Oscillation events and associated with strong SST anomalies.
Figure 6 presents DMS anomalies (DMSa; 1990-1999) as well as SST anomalies (SSTa) averaged for the area west of Amsterdam Island. These monthly DMS "anomalies" (DMSa) for this 10-year period have been calculated following equation (2): $\mathrm{DMSa}_{(\text {month i, year } k)}=100 \times\left[\mathrm{DMS}_{(\text {month }, \text { year } k)} /\right.$ median $\mathrm{DMS}_{1990}$ 1999 (month $t)$ - 1]. In other words, DMS anomalies were calculated as fractional / normalized values in percent. This put winter and summer data on an equal footing, greatly increasing the data record being analyzed. DMS anomalies have been retreated by using moving average on three points (thus smoothed on three months basis). SSTa were calculated using 10-year SST observations from satellites (IGOSS data) and the same procedure as for DMSa. Since westerlies represent roughly three fourths of the winds reaching the island, SST data from a point $3^{\circ}$ west of the island and for the period of DMS measurements (1990-1999) have been used. Note that if SST from Amsterdam Island is used, a similar pattern for SSTa is obtained. SST anomalies in percent were calculated as for DMS.

Almost all the peaks (negative and positive) in DMS anomalies were found in SST anomalies except two periods (A and B in Figure 6); one in 1992 (October 1991 to August 1992) and the other during 5 months (March-July) in 1998. When these two periods are not taken into account, DMS and SST present a very significant correlation $\left(r^{2}=0.65 ; n=97\right.$; Figure 7a).

To our knowledge, this is the first time that a direct link between SST and atmospheric DMS is established in a large oceanic area, in agreement with the CLAW hypothesis [Charlson et al., 1987].

It is important to note that the points belonging to periods $A$ and $\mathrm{B}$ also correlate significantly between them $\left(r^{2}=0.57 ; n=16\right.$; Figure $7 b$ ), although the sign is opposite. Future measurements will help us to define the frequency of these events as well as understand the reasons of this negative correlation.

Gabric et al. [1998] calculated that under doubled $\mathrm{CO}_{2}$ conditions, SST would increase by $4^{\circ} \mathrm{C}$ through the year. They also hypothesized that under such conditions, DMS flux would increase by $2-8 \%$. Our results indicate that increases in SST by $1{ }^{\circ} \mathrm{C}$ may cause changes in atmospheric DMS by up to $50 \%$ on a monthly basis. Thus a temperature increase by $4^{\circ} \mathrm{C}$ could, 


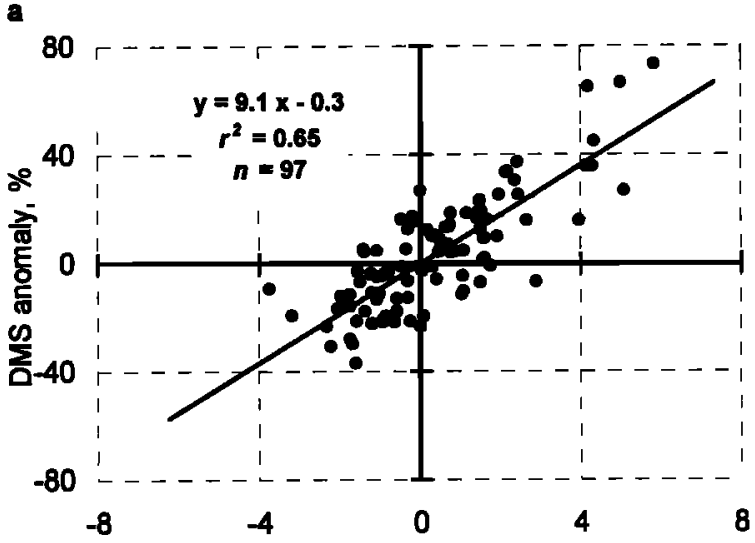

SST anomaly, \%

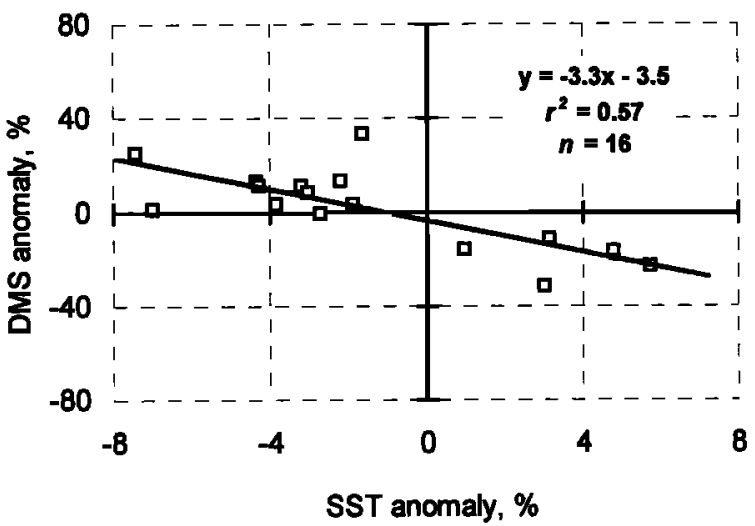

Figure 7. DMS anomalies versus SST anomalies for the data set displayed in Figure 6: excluding periods $A$ and $B$ (Figure 7a) and only for periods $A$ and $B$ (Figure $7 b$ ).

consequently, result in higher changes in DMS mixing ratios, which following the calculations performed by Gabric et al. [1998] will lead to very important radiative forcing. Considering the high seawater DMS levels recorded by Sciare et al. [1999] in the southern Indian Ocean, DMS could therefore play a very important role in regulating climatic changes at least in this area.

\section{Conclusion}

Continuous measurements of atmospheric DMS have been performed at Amsterdam Island between 1990 and 1999. From the analysis of this unique data set, several conclusions can be made.

1. Atmospheric DMS values recorded are among the highest reported in the literature and follow a well-distinguished seasonal variation in agreement with previous works previously performed at Amsterdam Island and Cape Grim.

2. An important year-to-year variability with "anomalies" up to $50 \%$ compared to the 10 -year mean value has been observed which could not be explained by changes in meteorology and/or oxidation capacity of the atmosphere.

3. A comparison with a 3-D chemistry/transport model revealed that these "anomalies" could be explained only by a change in the ocean DMS concentrations, which in some cases exceed a factor of 2 .

4. A simplifying approach by using smoothed SST and DMS anomalies showed a very good agreement $\left(r^{2}=0.65\right)$ with almost all of the SST anomalies reflected in DMS anomalies.

To our knowledge this is the first time that a direct link between SSTa and atmospheric DMS is established for a large oceanic area. Further analysis has to be performed to better improve this link. In addition, future studies based on concurrent ground-based measurements of atmospheric and seawater DMS and its oxidation products as well as satellite observations of both optical depth and ocean color will be very helpful to quantify the climatic importance of such natural DMS interannual variability.

Acknowledgments. We wish to thank J.P. Putaud as well as all the persons (VAT Soufre) in charge of the "Sulfur cycle" programme at Amsterdam Island, G. Ayers for communicating his Cape Grim DMS data, IFRTP for financial support and the two anonymous reviewers for their helpful and stimulating comments. The article is dedicated to B.C. Nguyen, pioneer of the biogeochemical sulfur cycle and initiator of the DMS measurements at Amsterdam Island.

\section{References}

Andreae, M.O., Ocean-atmosphere interactions in the global biogeochemical sulfur cycle, Mar. Chem., 30, 1-29, 1990.

Andreae, M.O., H. Berresheim, T.W. Andreae, M.A. Kritz, T.S. Bates, and J.T. Merill, Vertical distribution of dimethylsulfide, sulfur dioxyde, aerosols ions, and radon over the northeast Pacific Ocean, J. Atmos. Chem., 6, 149-173, 1988.

Andreae, M.O., W. Elbert, and T.W. Andreae, Non-sea salt sulfate concentrations at Cape Grim, 1988-1990, in Baseline 89, edited by S.R. Wilson and J.L. Gras, pp. 59-60, Impress Studios, Newcastle, Australia, 1991.

Andreae, M.O., W. Elbert, and S.J. de Mora, Biogenic sulfur emissions and aerosols over the tropical South Atlantic, 3, Atmospheric dimethylsulfide, aerosols, and cloud condensation nuclei, J. Geophys. Res., 100, 11,335-11,356, 1995.

Ayers, G.P., and J.L. Gras, Seasonal relationship between cloud condensation nuclei and aerosol methanesulphonate in marine air, Nature, 353, 834-835, 1991.

Ayers, G.P., J.P. Ivey, and R.W. Gillet, Coherence between seasonal cycles of dimethyl sulphide, methanesulphonate and sulphate in marine air, Nature, 349, 404-406, 1991.

Ayers, G.P., S.T. Bentley, J.P. Ivey, and B.W. Forgan, Dimethylsulfide in marine air at Cape Grim, $41^{\circ} \mathrm{S}, J$. Geophys. Res., 100, 21,013-21,021, 1995.

Bates, T. S., and P.K. Quinn, Dimethylsulfide (DMS) in the equatorial Pacific Ocean (1982 to 1996): Evidence of a climatic feedback?, Geophys. Res. Lett., 24, 861-864, 1997.

Bates, T. S., B.K. Lamb, A. Guenther, J. Dignon, and R.E. Stoiber, Sulfur emissions to the atmosphere from natural sources, $J$. Atmos Chem., 14, 315-337, 1992.

Belviso, S., R. Morrow, and N. Mihalopoulos, An Atlantic meridional transect of surface water DMS concentrations with 10 $15 \mathrm{~km}$ horizontal resolution and close examination of ocean circulation, J. Geophys. Res., J05, 14,423-14,431, 2000.

Berresheim, H., M.O. Andreae, G.P. Ayers, R.W. Gillet, J.T. Merrill, V.J. Davis, and W.L. Chameides, Airborne measurements of dimethylsulfide, sulfur dioxide, and aerosol ions over the Southern Ocean south of Australia, J. Atmos. Chem., 10, 341-370, 1990.

Charlson, R.J., J. Lovelock, M.O. Andreae, and S. Warner, Oceanic phytoplankton, atmospheric sulfur, cloud albedo and climate, Nature, 326, 655, 1987.

Dentener, F.J., J. Feichter, and A. Jeuken, Simulation of the transport of $\mathrm{R} 222$ using on-line and off-line global models at different horizontal resolutions: A detailed comparison with measurements, Tellus, Ser. B, 5l, 573-602, 1999.

Gabric, A., P. Whetton, R. Boers, and G.P. Ayers, The impact of simulated change on the air-sea flux of dimethylsulphide in the subantarctic Southem Ocean, Tellus, Ser. B, 50, 388-399, 1998.

Gibson, R., P. Kallberg, and S. Uppala, The ECMWF Re-Analysis (ERA) Project, ECMWF Newslett., 73, 7-17, 1997.

Heimann, M., The Global Atmospheric Tracer Model TM2, Dtch. Klimarechenzent., Hamburg, Germany, 1993.

Houweling, S., F.J. Dentener, and J. Lelieveld, The impact of nonmethane hydrocarbon compounds on tropospheric chemistry, J. Geophys. Res., 103, 10,673-10,696, 1998. 
Kettle, A. J., et al., A preliminary global database of sea surface dimethyl sulfide (DMS) measurements and a simple model to predict sea surface DMS as a function of latitude, longitude and month, Global Biogeochem., 13, 399-444, 1999.

Krol, M.C., and M.V. Weele, Implication of variation of photodissociation rates for global atmospheric chemistry,Atmos. Environ., 31, 1257-1273, 1997.

Landgraf, I., and P.J. Crutzen, An efficient method for online calculations of photolysis and heating rates, J. Atmos. Sci., 55, 863-878, 1998.

Liss, P.S. and L. Merlivat, Air-sea gas exchange rates: Introduction and system, The Role of Air-Sea Exchange in Geochemical Cycling, edited by P. Buat-Ménard, pp. 113-127, D. Reidel, Norwell, Mass., 1986.

Louis, J.F., A parametric model of vertical eddy fluxes in the atmosphere, Boundary Layer Meteorol., 17, 187-202, 1979.

Mihalopoulos, N., J.P. Putaud, and B.C. Nguyen, Seasonal variation of methanesulfonic acid in precipitation at Amsterdam Island in the southern Indian Ocean. Atmos. Environ., Ser. A, 27, 19091916, 1993.

Miller, J.M., J.L. Moody, J.M. Harris, and A. Gaudry, A 10-year trajectory flow Climatology for Amsterdam Island, 1980-1989, Atmos. Env., Ser. A, 1909-1916, 1993.

Nguyen, B.C., N. Mihalopoulos, and S. Belviso, Seasonal variation of atmospheric dimethylsulfide at Amsterdam Island in the southern Indian Ocean, J. Atmos. Chem., II, 123-143, 1990.

Nguyen, B.C., N. Mihalopoulos, J.P. Putaud, A. Gaudry, and L. Gallet, Covariations in oceanic dimethylsulfide, its oxidation products and rain acidity at Amsterdam Island in the southern Indian Ocean, J. Atmos. Chem., 15, 39-53, 1992.

Polian, G., G. Lambert, B. Ardouin, and A. Jégou., Long range transport of continental radon in subantarctic areas, Tellus, Ser. B, 38, 178-189, 1986.

Putaud, J.P., N. Mihalopoulos, B.C. Nguyen, J.M. Campin, and S. Belviso, Seasonal variations of atmospheric sulfur dioxide and dimethylsulfide concentrations at Amsterdam Island in the southern Indian Ocean, J. Atmos. Chem., 15, 117-131, 1992.

Putaud, J.P., S. Belviso, B.C. Nguyen, and N. Mihalopoulos, Dimethylsulfide, aerosols and condensation nuclei over the tropical northeastern Atlantic Ocean, J. Geophys. Res., 98, 14,863-14,871, 1993.
Russel, G.L., and J.A. Lerner, A new finite-differencing scheme for the tracer transport equation, J. Appl. Meteorol., 20, 1483-1498, 1981.

Sciare, J., N. Mihalopoulos, and B.C. Nguyen, Summertime seawater concentrations of dimethylsulfide in the western Indian Ocean Reconciliation of fluxes and spatial variability with long-term atmospheric observations, J. Atmos. Chem., 32, 357-373, 1999.

Sciare, J., M. Kanakidou, and N. Mihalopoulos, Diurnal and seasonal variation of atmospheric dimethylsulfoxide (DMSO) at Amsterdam Island in the southern Indian Ocean, J. Geophys. Res., $105,17,257-17,266,2000$ a.

Sciare, J., E. Baboukas, M. Kanakidou, U. Krischke, S. Belviso, H. Bardouki, and N. Mihalopoulos, Spatial and temporal variability of atmospheric sulfur-containing gases and particles during the Albatross campaign, J. Geophys. Res., 105, 14,433-14,448, 2000b.

Tiedke, M., A comprehensive mass flux scheme for cumulus parameterization in large-scale models, Mon. Weather Rev., 11 , 1779-1800, 1989.

Yvon, S.A., E.S. Saltzman, D.J. Cooper, T.S. Bates, and A.M. Thompson, Atmospheric sulfur cycling in the tropical Pacific marine boundary layer $\left(12^{\circ} \mathrm{S}, 135^{\circ} \mathrm{W}\right)$ : A comparison of field data and model results, 1, Dimethylsulfide, J. Geophys. Res., 101, 6899-6909, 1996.

F.J. Dentener, IMAU University of Utrecht, Princetonplein 5, 3584 CC Utrecht, The Netherlands.

N. Mihalopoulos (corresponding author), Environmental Chemical Processes Laboratory, Department of Chemistry, University of Crete, P.O. Box 1470, 71409 Heraklion, Greece. (mihalo@chemistry.uch.gr).

J. Sciare, Laboratoire des Sciences du Climat et de l'Environnement, CEA Orme des Merisiers, 91191 Gif-Yvette Cedex, France. (sciare@lsce.saclay.cea.fr).

(Received October 25, 1999; revised April 6, 2000; accepted April 12, 2000.) 